\title{
PENERAPAN FIQH DI TENGAH PERBEDAAN MAZHAB HUKUM ISLAM
}

\author{
Moh. Dliya'ul Chaq \\ Institut Agama Islam Bani Fattah Jombang, Indonesia \\ mohdliyaulchaq@iaibafa.ac.id
}

Abstract: Fiqh always attracts the attention of the public, both experts and laity, because it functions as a living law in society. The need for fiqh has triggered a phenomenon lately about the discussion of Islamic law on social media that is increasingly compilation has reached the justification of right or wrong and is done by people who are not competent in the field of Islamic law. This phenomenon is due to lack of fiqh knowledge possessed by those who argue and their awareness of the inevitability of differences in the world of Islamic law. This is what drives a study to be carried out with the focus of purpose on how the causal factors in fiqh always differ and how the application of fiqh in the midst of the preaching of figh Mazhab. By using the literature research model and with qualitative analysis with descriptiveanalytical thinking models, it is concluded that: First, the factors that cause fiqh are always different is a source of theory and practical aspects for fiqh itself. Secondly, in the midst of differences of Mazhab, only fiqh that is in accordance with the environment and society can be a living and effective law in the community so that it does not form a general public and does not cause sentiment between groups. This is in accordance with the principles of the application of Islamic law which contains relief (takhfif), ease (taysic $>$ and conservation of hazards and damage all of which

Tafáqquh: Jurnal Penelitian dan Kajian Keislaman

Volume 7, Nomor 2, Desember 2019 ; p-ISSN 2338-3186; e-ISSN 2549-1873; 51-66 
are complete and clearly oriented to maqa shari and maslahtht.

Keyword: The application of Fiqh, Mazhab Difference, Islamic law

\section{Pendahuluan}

Hukum Islam atau yang diistilahkan dengan figh memang selalu menarik perhatian karena fungsinya sebagai hukum yang hidup di masyarakat. Fungsi ini sebagaimana diisyarahkan oleh Imam Badr al-Di al-Zarkashi (w.794 H) dalam bukunya al-Babr\}al-Mubi fyang mengatakan bahwa fiqh pada dasarnya adalah pengetahuan yang mencakup semua aturan agama yang mengantarkan manusia pada pengetahuan tentang Tuhan, ke-Esa-an Tuhan, dan sifat-sifat-Nya, para nabi dan rasul-Nya, tentang tingkah laku manusia, etika (akblaq), apa yang perlu dilakukan oleh manusia sebagai hamba-Nya, dan lain-lain. ${ }^{1}$

Sebagai seorang hamba, setiap manusia merasa butuh terhadap fiqh. Oleh karenanya fiqh selalu menarik perhatian masyarakat ahli maupun awam. Hal ini memicu sebuah fenomena akhir-akhir ini, di mana perdebatan hukum Islam menjadi ramai di media sosial. Kondisi kian miris ketika perdebatan sudah mengarah pada justifikasi benar atau salah dan dilakukan oleh orang yang tidak berkompeten di bidang hukum Islam. Tentu hal ini tidak sesuai dengan nalar fiqh yang diperdebatkan itu sendiri.

Fiqh merupakan salah satu dari disiplin ilmu keislaman yang ada. Dalam dunia penelitian dan keilmuan menurut Ahmad Zahro terdapat konvensi tidak tertulis bahwa kemungkinan validitas (kadar kebenaran), realibilitas (tingkat kepercayaan) dan signifikansi (arti penting) suatu hasil penelitian hanya berlaku dalam rentang waktu dua sampai lima tahun. Lebih dari itu dapat atau bahkan harus diadakan penelitian ulang untuk meninjau atau mengoreksinya. ${ }^{2}$ Artinya, fiqh memang layak diperdebatkan, namun dengan cara yang ilmiah.

Fenomena perdebatan hukum Islam inilah yang mendorong untuk dilakukan sebuah kajian atau penelitian tentang fiqh. Bertumpu pada latar belakang tersebut, maka stressing yang menjadi rumusan masalah dalam

\footnotetext{
${ }^{1}$ Badr al-Di $\$$ al-Zarkashisal-Bahr\}al-Mubi- (Beirut: Dar al-Kutub al-Ilmiyyah, 2000), Jilid I, 16.

${ }^{2}$ Ahmad Zahro, "Desakralisasi Kitab Fiqh Sebagai Upaya Reformasi Pemahaman Hukum Islam”, Menara Tebuireng, Vol. 2, No. 1 (September, 2005), 9. 
karya ini adalah bagaimana faktor penyebab fiqh selalu ikhtila $\$$ dan bagaimana penerapan figh di tengah ikhtilaf fiqh Mazhab yang ada.

Untuk menjawab rumusan masalah penelitian ini, metode yang digunakan dalam karya ini adalah penelitian kepustakaan karena datadatanya bersifat literer. Selanjutnya, analisa datanya menggunakan analisa kualitatif dengan model berfikir desriptif-analitis. Data kualitatif tentang ikhtila $\$$ dalam fiqh dideskripsikan dan kemudian dianalisa untuk kemudian ditarik sebuah kesimpulan.

\section{A. Fiqh dan Keniscayaan Ikhtilanya}

Definisi fiqh dalam ranah historis mengalami beberapa perubahan sesuai dengan perkembangan fiqh itu sendiri, sebagiamana diungkap Qadri Azizy. ${ }^{3}$ Dan pada fase dianggap paling akhir, fiqh didefinisikan dengan pengetahuan tentang hukum-hukum shariat amaliyyah (berhubungan dengan perbuatan) yang digali dari dalil-dalil yang terperinci. ${ }^{4}$ Teramati bahwa dari definisi fiqh yang masyhur dipakai ini, bahwa fiqh tersusun atas tiga aspek, yakni aspek kewahyuan, aspek teoritis dan aspek praktis.

Dalam aspek kewahyuan, betapapun beragam definisi fiqh, namun terdapat kesamaan yang menjadi ciri khas fiqh, yaitu tergambarkan pada teks “"الأحكام الشرعية", yakni ketergantungan fiqh terhadap sumber refrensi wahyu atau nasł\} 3 hari baik yang berbentuk al-Qur'aæmaupun al-Hadi (al-Sunnab)..$^{5}$ Aspek kewahyuan ini oleh Hasjim Abbas diistilahkan dengan jarbal-dirau jal-shar'is

Aspek kewahyuan ini menekankan pada hubungan erat tak terpisahkan antara fiqh dengan teks wahyu/shariat sebagai sumber refrensi utamanya. Hal ini dapat dilihat pada semua produk fiqh yang pasti menyertakan ayat atau hadith sebagai landasan hukumnya. ${ }^{7}$ Selain

${ }^{3}$ Lihat A. Qadri Azizy, Ekleksitisme Hukum Nasional: Kompetisi antara Hukum Islam dan Hukum Umum, (Jogjakarta: Gama Media, 2002), 2.

${ }^{4}$ Baca Wahbah Zuhłyli,al-Fiqh al-Isla $\rightarrow$ fra Adillatubu Vol I, (Beirut: Daßal-Fikr, 2000), 14.

5 Al-Hadith atau al-Sunnah tergolong sebagai kalam Ilahi mengingat kedudukan Rasulullah SAW sebagai penyalur wahyu Allah swt. Oleh karenanya segala yang keluar dari Rasulullah SAW adalah wahyu Allah sebagaimana penjelasan al-Qur'aæ. وَمَ يَنْقُق عَنِ الْوَى إِنْ هُوَ إِلَّا وَحْيُ يُوحَى (al-Najm 53: 3-4)

${ }^{6}$ Hasjim Abbas, Metodologi Penelitian Hukum Islam, (Jombang: PPS UNDAR, 2010), hal. 4.

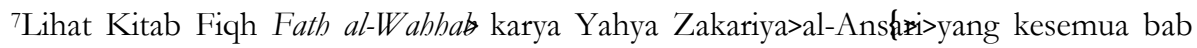
pasti diawali dengan penyertaan teks wahyu, baik berupa al-Qur'a $>$ maupun al-Hadi Lihat juga Kitab Fiqh Bidayat al-Mujtabid Wa Nihayat al-Muqtasifl karya Ibnu Rusyd yang 
itu, aspek kewahyuan dapat diamati dari pemberian status wajib, sunnah, boleh, makruh dan haram yang biasa disebut dengan al-ahkaral-khamsah yang kesemua status tersebut terorientasi pada terwujudnya kandungan nilai ibadah yang sarat dengan pahala (thawals dan siksa ('iqa) dan berkonsekwensi akhirat. ${ }^{8}$

Maka, predikat hukum Islam yang diistilahkan dengan al-abkam alkhamsah lebih identik dengan etika agama (religiuos etbics), sekalipun fiqh mengatur tentang masalah sosial, ekonomi, dan lainnya, namun kandungan nilai ibadah dalam aturan tersebut menjadi titik tekan yang membedakan antara fiqh dengan aturan atau sistem hukum lainnya. Sehingga fiqh tidak dapat diidentikkan juga sebagai peraturan perundangundangan (law/rules) murni.

Dengan melihat aspek kewahyuan, maka fiqh cenderung dogmatis, sehingga tidak salah jika fiqh diistilahkan dengan hukum islam yang diyakini dapat memastikan bahwa prilaku manusia akan berada pada jalur yang benar dan selalu memiliki kesinambungan pada maslahat duniawiukhrawi. Penekanan maslahbat tersebut sesuai dengan pendapat al-Shatoi> dan Izz al-DiæIbnu 'Abd al-Salał bahwa taklifhukum islam / fiqh pasti berorientasi pada maqa shari dan maslahb dt.

Pemahaman senada dirumuskan KH. A. M. Sahal Mahfudz yang menyatakan bahwa kehidupan adalah amanat yang harus digunakan untuk pencapaian sa'alab al-daroyni (kesejahteraan dunia dan akhirat). Pemenuhan kebutuhan spiritualitas jelas menjadi tuntutan utama, karena kebahagiaan akhirat yang bersifat permanen dapat diwujudkan hanya bila manusia mampu memenuhi kebutuhan spiritualnya. Tetapi bersamaan dengan itu manusia dihadapkan pada kenyataan bahwa ia harus tunduk dan patuh pada hukum-hukum yang mengikat kehidupannya pada saat ini. Maka kehidupan dunia yang sepenuhnya bersifat temporer dan maya berhubungan secara integratif dan kausatif dengan kebahagiaan ukhrowi yang kekal dan hakiki. Meskipun selintas tampak kontradiktif, sebetulnya

kesemua pendapat ulama' pasti didasarkan pada teks wahyu sekalipun terjadi perbedaan penadapat. Dan lihat juga beberapa kitab fiqh lainnya.

${ }^{8}$ A. Qadri Azizy, Reformasi Bermadæhab, Sebuah Ikhtiar Menuju Ijtihad Saintifik-Modern, (Jakarta: Teraju, 2006), 14., A.Qadri Azizy, Ekleksitisme, 13.

${ }^{9}$ Muhammad Sijdqi $>a l-B u r n u>A l-W$ aji $\gg$ fi $>$ al-Qawa al-Fiqhi $>$ al-Kullizah, (Riyad:\} Maktabat al-Tawbah, tt), 229., Izz al-Di\$ Ibnu 'Abd al-Salał, Qawa al-Abla Masd Jal-Ana Vol II, (Beirut: Da $\gg$ al-Kutub al-'Ilmiyyah, t.th.), 72., Ibrałi Ibnu Musa $\gg 1$ l-Sha 
tidak ada yang aneh dalam hal itu, sebab akhirat hanya menyediakan satusatunya jalan bagi pencapaiannya, yaitu kehidupan dunia. ${ }^{10}$

Dengan demikian, fiqh adalah satu-satunya hokum yang memiliki ciri khas berupa refrensi utamanya adalah wahyu, bukan akal semata sebagaimana hukum sekuler produk bangsa barat. Karenanya, fiqh bersifat dogmatis namun tetap mengarah pada kemaslahatan duaniawi dan ukhrawi secara bersamaan.

Selanjutnya tentang aspek kognitif dalam fiqh, bahwa konsekwensi logis dari definisi fiqh pada teks “المكتسب من أدلتها التفصيلية" adalah adanya penggunaan nalar mujtahid dalam perumusannya. Peran nalar mujtahid menempati posisi penting dalam upaya perumusan fiqh untuk menjadikan kaidah shari atau wahyu yang masih in abstracto menjadi hukum praktis in concreto. ${ }^{11}$ Upaya atau proses mujtahid tersebut telah memanfaatkan jasa metodologi hukum Islam yang terumuskan dalam ust) l-fiqh (legal theory) dan qawa al-figh (legal maxim). Terkadang mujtahid menggunakan metode deduktif dalam bentuk teori qiyasłanalogi atau juga kaidah lughawiyyah, dan terkadang menggunakan metode induktif

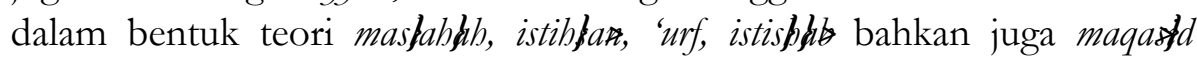
shaw. Kesemua teori dan metode tersebut terumuskan dalam istilah usifal-fiqh (legal theory) dan qawa al-fiqh (legal maxim).

Nisbah fiqh pada perumusnya sebagaimana istilah Mąhab makiyyah yang dinisbahkan pada Imam Ma dan Mą̧ab-Mą̧ab yang lain merupakan fakta sejarah yang tidak bisa dipungkiri tentang corak nalar mujtahid yang beragam. Maka, aspek kognitif yang diistilahkan dengan jałtb al-nazłr teramati wajar jika kemudian fiqh cenderung ikhtilasebagai implikasi logis atas penggunaan nalar mujtahid mengingat masing-masing mujtahid pasti berbeda dalam menggunakan teori dan juga kapasitas keilmuannya. Selain itu faktor kondisi tempat tinggal dan sosial-budaya yang melingkupi mujtahid juga mempengaruhi corak dan hasil pemikirannya mengingat mujtahid, menurut Nasaruddin Umar, merupakan anak zamannya. ${ }^{12}$

Terakhir, bahwa implikasi logis dari definisi fiqh selanjutnya adalah adanya aspek praktis yang terumuskan dalam teks definisi "'العملية". Aspek ini oleh Wahbah Zuhłyli جliistilahkan dengan jarb al-'amali>Maksudnya,

10 A. Sahal Mahfudz, "Menggagas Fiqh sosial yang berbasis pada kearifan Lokal", Makalah Kuliah Umum Studium General Kulliyyatusy Syari'ah IKAHA Tebuireng Jombang 8 September 2007 di Tambakberas Jombang (Jombang: 2007) hal. 5.

${ }^{11}$ Baca Hasjim Abbas, Metodologi, 4-5.

${ }^{12}$ Nasaruddin Umar, Argumen Kesetaraan Jender Perspektif Al-Qur'an, (Jakarta: Dian Rakyat, 2010), 275. 
shari merupakan segala yang datang dari Allah baik yang berhubungan dengan perilaku, aqidah keyakinan hati maupun akhlaq, sedangkan fiqh adalah salah satu bagian dari shari yang khusus berkaitan dengan tata cara berperilaku. ${ }^{13}$ Dengan bahasa lain yang mudah, objek kajian fiqh adalah perilaku manusia, sehingga hasil penggalian hukum yang disebut dengan fiqh juga harus bersifat terapan praktis. Hal inilah yang membedakan fiqh dengan disiplin ilmu tauhid, ilmu kalam, ilmu akhlaq dan tasawuf.

Konsekwensi dari perilaku manusia sebagai objek kajian fiqh adalah selain keniscayaan hasil produk fiqh tertuntut bersifat praktis, terapan atau tidak normative, juga produk hukumnya akan beragam bersanding dengan objek kajiannya yang beragam. Misalnya, masyarakat daerah Timur Tengah pasti memiliki aktifitas berbeda dengan masyarakat Eropa. Hal ini mendorong adanya hokum yang berbeda pula.

Konsekwensi yang lain dari perilaku manusia sebagai objek kajian fiqh adalah adanya pengalaman "ber-fiqh" mujtahid beragam. Pengalaman praktis individu mujtahid inilah sedikit banyak mempengaruhi perilaku dan pemikirannya. Di sisi lain, faktor kondisi masyarakat, tempat tinggal dan sosial-budaya yang melingkupi mujtahid juga menjadi bahan pertimbangan sehingga sarat mempengaruhi corak dan hasil pemikirannya mengingat mujtahid menurut merupakan anak zamannya yang tidak mudah melepaskan diri dari pengaruh lingkungannya. ${ }^{14}$

Salah satu bukti konkret betapa faktor lingkungan sosial budaya menjadi pertimbangan mujtahid dalam merumuskan fiqh adalah munculnya dua pendapat Imam Shałi łang dikenal dengan qaul qadiæ dan qaul jadi Pendapat lama (qaul qadim) adalah pendapat hukum Imam Syafi'i ketika beliau berada di Mesir. ${ }^{15}$ Perbedaan pendapat hukum dalam masalah yang sama dari seorang mujtahid Imam Sha ielas disebabkan faktor struktur sosial, budaya, letak geografis yang berada antara daerah Iraq (Baghdad) dan Mesir. Bukti lain betapa faktor geografis dan demografis mempengaruhi kodifikasi figh adalah Mazhab kedaerahan, seperti Mą̧ab hifa Mekkah dan Madinah), 'ira Kufah dan Bashrah), Sham (Syiria) dan Mis? Mesir). Kesemua Mą̧ab ini memiliki perbedaan produk hukum satu dengan lainnya. ${ }^{16}$

\footnotetext{
${ }^{13}$ Wahbah Zuhłyli, ,al-Figh al-Islami ol. I, 16.

${ }^{14}$ Nasaruddin Umar, Argumen Kesetaraan Jender, 275.

${ }^{15}$ M. Atho' Muzdhar, Membaca Gelombang Ijtibad antara Tradisi dan Liberasi, (Yogyakarta: Titian Ilahi Press, 1998), 107.

${ }^{16}$ A Qadri Azizy, Ekleksitisme, 21-22. 
Menurut pengamatan Qadri Azizy, istilah Mazhab kedaerahan muncul lebih awal dari pada Mazhab individual. Setelah Maz̧ab yang dinisbahkan pada sebuah daerah, barulah muncul istilah Mą̧ab yang dinisbatkan pada individu, seperti Maz̧hab hqnafiyyah di Iraq yang

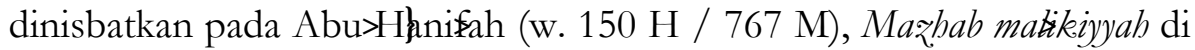
Madinah yang dinisbatkan pada Imam Ma (w 179 H / 795 M), Mą̧bab shajyah yang dinisbatkan pada Imam Sha

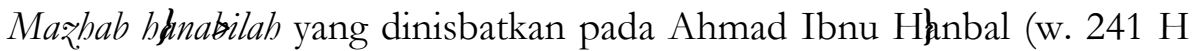
/ 855 M). Semua Mą̧ab ini memilki corak pemikiran dan produk hukum yang berbeda-beda yang menurut para ahli perbedaan tersebut disebabkan faktor geografis dan sosial-budaya sebagai pertimbangannya. ${ }^{17}$ Bahkan menurut para liberalis Islam, diantaranya Abdullah Ahmed al-Na'im mengatakan penyebab perbedaan Maŗab tidak hanya karena faktor sosial-budaya semata, namun juga terpengaruh faktor politik sejak tahun sekitar $750 \mathrm{M}^{18}$

Terkait perbedaan Mą̧bab, Imam Sha $\$$ pernah menyampaikan: "Saya mengetahui bahwa masyarakat di sebuah kota berbeda pendapat, dan juga terjadi perbedaan pendapat antara satu kota dengan kota lainnya. Kita tahu bahwa hampir tak seorang pun masyarakat Mekkah menyimpang dari pendapat 'At $>$ >ibnu Abi $\operatorname{Raba}_{3}($ w. 144/732) yang difatwakan Muslim Ibnu Khalid al-Zanji>(w. 179/795). Sebagian masyarakat Mekkah cenderung pada pendapat Said ibnu Sam. Masingmasing pendukung saling melemahkan pendapat. Masyarakat Madinah lebih mengedepankan Sa'id Ibnu al-Musayyab (w 94/712) walaupun sebagian menolak pendapatnya. Dan saat ini saya dan masyarakat madinah lebih menyukai pendapat Imam Ma sekalipun Abi Zina banyak mengecam pendapatnya dan juga didukung sebagian masyarakat. Di Kufah, masyarakat ada yang menyukai Ibnu Abi ₹ayla $>a d a$ yang menyukai Abu $¥$ Yusuf, ada yang menyukai Sufya $\gg$ al-Thawri $>$ ada yang

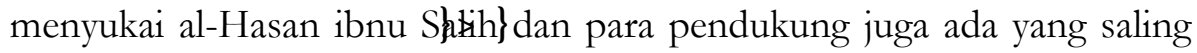
mengecam. Di Iraq saya melihat masyarakat lebih menyukai pendapat Ibrałim al-Nakha’iłetimbang tabi'iælainnya..."

Fakta ini secara tegas menolak anggapan dan tesis Schacht yang menyatakan bahwa hukum Islam telah vakum selama 100 tahun pasca

\footnotetext{
${ }^{17}$ A Qadri Azizy, Ekleksitisme, 21-22., Abdullah Ahmed al-Na'im, Dekontruksi Syari'ah, terj: Ahmad Suaedy dan Amiruddin ar-Rany, (Jogjakarta: LKiS, 2011), 28-29.

${ }^{18}$ Saat itu, era Abbasiyyah awal mulai terjadi proses konsolidasi dan sistematisasi karya ahli hukum tertentu dan murid-murid mereka ke dalam pemikiran madhhab syariah tersendiri. Lihat Abdullah Ahmed al-Na'im, Dekontruksi Syariah, 29.

${ }^{19}$ Muhammad Ibnu Idris al-Shaßi
} 
wafatnya Nabi Muhammad SAW. Selain itu, ungkapan al-Sha $\$$ i atas menunjukkan bahwa pada masa ta tolah terjadi perbedaan fiqh kedaerahan yang bersifat individual dan independen. Senada dengan Abdullah Ahmed al-Na'im bahwa kontruksi hukum Islam yang dimulai pada abad ke II H dibangun atas dasar karya individual para ahli yang hidup di sejumlah pusat Islam, yakni Mekkah, Madinah, Bashrah, kufah, Damaskus, dan Mesir. Karena sifatnya yang individual dan independen, karya ahli hukum pada abad ini dicirikan oleh luasnya kandungan lokal yang diterima secara wajar dan sah. ${ }^{20}$

Nasaruddin Umar menyatakan bahwa fiqh yang diproklamirkan oleh Mazhab ma iyyah, homafiyyah, shajiyyah dan hanaliab merupakan fiqh yang terpengaruh dan terikat dengan kondisi sosial budaya tempat mereka hidup. ${ }^{21}$ Selanjutnya fatwa dan karya para imam Mazhab tersebut tersebar ke seluruh dunia bersamaan dengan transmisi keilmuan para pengikutnya. Sehingga banyak sekali ulama' setelahnya yang juga merujuk kontruksi fiqh klasik buatan Mąhab tersebut. ${ }^{22}$ Menurut Abdurrahman Wahid, Munculnya imam-imam Mazhab tidaklah dengan sendirinya dapat memenuhi kebutuhan hukum masyarakat. Bahkan karena tingkat toleransi di antara Mazhab sedemikian besar, hampir tidak ditemukan kodifikasi hukum Islam yang seragam untuk semua negara, atau wilayah yang berbeda-beda dalam sebuah negara. Sampai saat ini barulah alMajallat al-Ahka al-Adliyyah yang dianggap sebagai kodifikasi hukum Islam yang universal. ${ }^{23}$

Dari uraian ketiga aspek yang terkandung dalam figh, dapat disimpulkan bahwa fiqh merupakan hasil komunikasi nalar manusia (mujtahid) dengan teks wahyu dan setting sosial-budaya yang melatar belakangi pemilik nalar. Justifikasi bahwa fiqh merupakan hukum Tuhan sangat dibenarkan mengingat fiqh selalu dan pasti bersandar pada teks wahyu sebagai ciri khasnya yang berbeda dengan hukum sekuler atau hukum lainnya. Namun demikian, penggunaan nalar dan faktor sosialbudaya dalam perumusan figh menunjukkan bahwa fiqh bukan produk Tuhan, tetapi fiqh adalah produk fuqaha atau produk sejarah.

Namun demkian, karena figh merupakan hasil pembacaan terhadap wahyu, maka terdapat implikasi logis yang menjadi ke-khas-an

\footnotetext{
${ }^{20}$ Abdullah Ahmed al-Na'im, Dekontruksi Syari'ah, 28-29.

${ }^{21}$ Nasaruddin Umar, Argumen Kesetaraan Jender Perspektif Al-Qur'an, (Jakarta: Dian Rakyat, 2010), 271.

22Nasaruddin Umar, Argumen Kesetaraan Jender, 272.

${ }^{23}$ Abdurrahman Wahid, "Menjadikan Hukum Islam Sebagai Penunjang Pembangunan", dalam Hukum Islam di Indonesia Pemikiran dan Praktek, ed. Tjun Surjaman, et al. (Bandung: Rosda Karya, 1991), 3.
}

58 Moh. Dliya’ul Chaq - Penerapan Figh di Tengab Perbedaan Maźab 
dalam fiqh, yaitu fiqh harus bertujuan untuk kemaslhhłtan manusia di dunia dan akhirat, sebagaimana diungkap Izz al-Di $\$$ Ibnu 'Abd al-Salaær bahwa segala usaha harus dikembalikan kepada kepentingan manusia, dunia dan akhirat. ${ }^{24}$ Begitupun al-Sha bidang hukum harus bermuara pada tujuan terwujudnya kemaslahatan

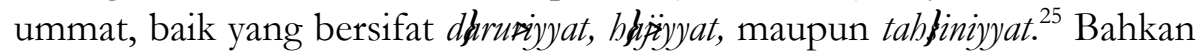
al-Burnu $>$ merusmukannya sebagai tuntutan fiqh harus tetap berlaku efektif dan berkesesuaian dengan asas penerapan hukum Islam berupa penciptaan keringanan (takhfif), kemudahan (taysi $>$ dan penolakan bahaya serta kerusakan yang kesemuanya berorientasi pada maqa shari dan maslahbetr. ${ }^{26}$

\section{Masl]ah\{̨h Dalam Fiqh}

Telah menjadi kesepakatan ulama bahwa shari Islam dibuat dalam rangka mewujudkan keadilan dan kemaslahatan umat manusia di dunia maupun akhirat. 'Izz al-diæ ibn Abd al-Salam mengungkapkan bahwa setiap tindakan hukum dimaksudkan untuk kemaslahatan umat manusia, baik di dunia maupun akhirat. Hukum tidak dimaksudkan untuk kepentingan Allah, karena Allah tidak membutuhkan manusia. Kebaikan manusia tidak menambah kebesaran Allah dan kejahatan manusia tidak akan mengurangi kebesaran-Nya. Oleh karena itu, lanjutnya, setiap tindakan hukum yang tidak memenuhi tujuan tersebut adalah salah. ${ }^{27}$

Standar maslahb adalah mengandung maqa shari yang menurut al-Gazal\$alan al-shætibi $\gg$ dalah pemeliharaan atas lima hal, yakni agama, jiwa, keturunan, harta dan akal, yang merupakan bentuk keharusan yang oleh al-Sha ofi diistilahkan dengan maqa daruriyyat yang kesemuanya kembali pada penghapusan segala bentuk kesulitan serta bahaya dan menarik manfaat, baik di dunia maupun akhirat. ${ }^{28}$ Menolak segala bentuk mafsadat dan maddrat yang berkaitan dengan kelima aspek tersebut juga dinamakan maslahb dit. ${ }^{29}$

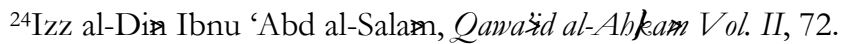

${ }^{25} \mathrm{Al}-\mathrm{Sh}$ a $\mathrm{Ai}$;al-Munawafaqa® ol II, 4.

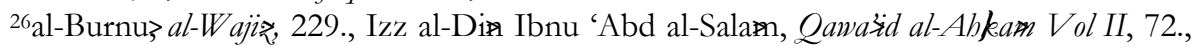
Al-Shatoiral-Muwarafaqa®l ol II, 4.

${ }^{27} \mathrm{Izz}$ al-DiæIbnu 'Abd al-Salaær, Qawa al-Abla $\mathrm{V}$ ol II, 73.

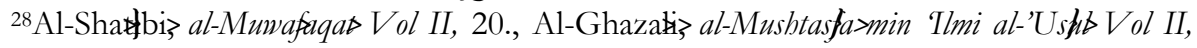
(Beirut: Dar Ihya $\gg l-T u r a$ al-'Arabi $\rightarrow$ th.

${ }^{29}$ Al-Ghazal $\gg$ al-Mushtasfa $\ngtr$ ol II, 287., Nasrun Haroen, Ushul Fiqh I, (Jakarta: Logos Publishing House, 1996), 114.
} 
Implementasi maslahb menurut al-Shatofi>lapat dilihat dari segi eksistensinya dalam realitas (mawał' al-wuju dan dari segi hubungannya

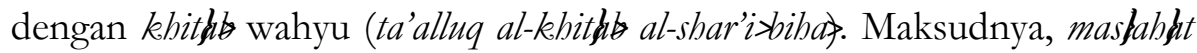
dan mafsadah di dunia dapat dilihat dari kebiasaan masyarakat menilai dan merasakan implikasinya, jika menimbulkan kemudahan maka dianggap masläh det dan jika menyengsarakan maka dianggap mafsadah, oleh karenanya implementasinya harus melihat eksistensinya dalam realitas yang erat penilaiannya dengan kebiasaan atau 'urf.

Sedangkan maqa shari antara hukum satu dengan lainnya berbeda tekanannya. Ibadah lebih ditekankan pada pemeliharaan agama, hukum adat lebih ditekankan pada pemeliharaan jiwa dan akal, sedangkan hukum mu'amalat (interaksi sosial) lebih diutamakan penekannanya pada pemeliharaan keturunan dan harta, namun jika mu'a alat berhubungan erat dengan kebiasaan maka juga menekankan maqa $\$$ berupa pemeliharaan jiwa dan akal. Maka kepemilikan hak yang disertai dengan akad seperti nikah, penekanan maqa shari lebih pada pemeliharaan keturunan dan harta. ${ }^{31}$

Dari uraian di atas, dapat disimpulkan bahwa setiap hukum (fiqh) harus mengandung maslahłt. Apa yang disampaikan oleh Imam alSha $\mathrm{i}>\mathrm{di}$ atas menunjukkan bahwa maslahat dalam fiqh harus dapat terukur pada dua dimensi fiqh, yaitu pada dimensi penggalian hukum

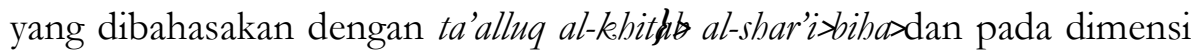
penerapan hukum yang dibahasakan dengan mawap̀' al-wujula.

Perdebatan panjang tentang maslahat sebagai subtansi hokum ataukah implikasi hokum, sebenarnya terjawab oleh uraian di atas yang

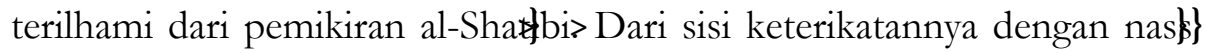
dan urgenisinya sebagai subtansi hokum, maslhh łt masuk dalam kajian penggalian hokum. Sedangkan dari sisi implikasinya, maslłh ł masuk dalam kajian penerapan hokum.

\section{Penerapan Fiqh di Tengah Perbedaan Mazhab}

Teramati, ada dua sisi penting dalam setiap penetapan hukum, yaitu sisi penggaliannya dan sisi penerapannya. Sisi penerapan fiqh tidak kalah penting dari penggaliannya. Betapa indahnya hukum yang dihasilkan dari sebuah teks wahyu, namun jika tidak tepat dalam penerapannya, maka hukum tersebut menjadi hukum yang tumpul. Oleh

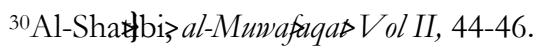

${ }^{31}$ Ibid, 18-20.

60 Moh. Dliya'ul Chaq-Penerapan Figh di Tengab Perbedaan Mazbab
} 
karenanya, penerapan fiqh harus memperhatikan banyak faktor yang memunculkan maslahat.

Sł $\}$ Awad Jmengutip pendapat al-Qaraßłang menyatakan bahwa seyogyanya seorang mufti ketika diminta fatwanya oleh seseorang harus menanyai peminta fatwa perihal daerah, Mað̧ab yang dianutnya dan juga kondisi serta kebiasaan masyarakat dalam daerah tersebut karena kebiasaan yang berbeda pada dua daerah tidak dapat memiliki hukum yang sama, begitu juga kebiasaan pribadi peminta fatwa. ${ }^{32}$ Oleh karenanya seorang mufti tidak boleh memfatwakan hukum kepada peminta fatwa dengan Mazhab dan hukum yang berlaku didaerah mufti jika peminta fatwa memiliki kebiasaan dan Mazhab yang berbeda. ${ }^{33}$

Pendapat al-Qara خni lebih menekankan bahwa penerapan fiqh harus benar-benar mempertimbangkan kondisi lingkungan dan subjek hukum, bukan penggali hukum (mujtahid/mufti). Contoh konkritnya adalah praktek ibadah haji di Mekkah. Orang Indonesia tertuntut menerapkan fiqh Mazhab ma ima dalam melaksanakan thawaf yang tidak menganggap batal persentuhan kulit antara lain jenis. Karena jika mempertahankan fiqh Mazhab sha ipah, maka dipastikan akan kesulitan melakukan thawaf sebab kondisi berdesakan yang sulit dihindari.

Namun penerapan fiqh yang seperti ini seringkali dihadapkan pada dua teori besar yang telah masyhur dalam hukum Islam, yaitu teori larangan pengambilan hukum yang mudah dan teori stratifikasi qoul fuqaha?

Larangan talfiф (pencampuradukan hukum) dalam menerapkan hukum menurut sebagian ulama' akan mengarah pada pengambilan hukum yang mudah saja. Hal ini dilarang agama. ${ }^{34}$ Imam al-Ramli Tokoh Sha ipah berpendapat bahwa berpindah Mazhab diperbolehkan asalkan tidak bertujuan untuk mencari kemudahan dalam beragama. ${ }^{35}$ Pendapat Imam al-Ramli ini senada dengan pendapat Imam al-Ghazali dan alSubkis

Bahkan, Imam Ahmad bin Hanbal terhadap orang yang mengambil hukum yang mudah saja dalam beragama menilainya sebagai orang yang fasiq karena menurutnya ada usaha menggugurkan tuntutan Allah dan melaksanakan hukum sesuai hawa nafsunya, sebab

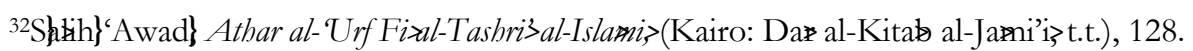
33Ibid, 128.

${ }^{34}$ Muhammad Mahraban, al-Ijtiha wa al-Taqli Bayna al-Afratua al-Tafrit Beirut: DaßalKutub al-Ilmiyah, 1971), 175.

35 Ibid, 175.

${ }^{36}$ Ibid, 176.
} 
melaksnakan hukum sesuai hawa nafsu bertentangan dengan ayat 59 dalam surat al-Nisa $?^{37}$

Sementara itu, bagi sebagaian ulama' menyatakan bahwa mengambil hukum dari berbagai Mazhab sekalipun tujuannya untuk mencari yang mudah itu diperbolehkan. ${ }^{38}$ Imam al-Qara\$>mayoritas sha ipah dan al-Kamałibnu al-Humam menyatakan bawa tidak ada dalil yang melarang tentang hal ini. ${ }^{39}$ Imam 'Izzuddin bin Abd Salam juga menyampaikan bahwa orang bodoh ('ałi >boleh mengamalkan hukum yang mudah dalam berbagai Mazhab karena mengambil yang mudah (rukhshah) itu disukai dan agama Allah itu mudah sebagaimana ayat 78 dalam surat al-Hajj. ${ }^{40}$

Ibnu Nujaym merujuk pada pendapat al-Kama\ibnu al-Humam menyatakan bahwa tidak ada dalil naqli maupun aqli tentang larangan mengambil hukum yang mudah. Bahkan Rasulullah mencintai yang ringan pada umatnya. ${ }^{41}$

Selanjutnya, Wahbah Zuhayli berpendapat bahwa mengambil hukum yang mudah dalam beragama untuk kepentingan hawa nafsu tidak diperbolehkan sebagaimana juga berpindah Mazhab untuk mecari hukum yang ringan. Larangan ini untuk menghindarkan dari upaya pembebasan diri dari hukum (tuntutan) shariat. ${ }^{42}$ Wahbah Zuhaili juga berpendapat bahwa tidak boleh talfiథ berakibat pada: (a) rusaknya ketetapan hakim, (b) mengembalikan taqlid seseorang (c) pertentangan hukum yang telah disepakati mayoritas (d) terjatuh pada perkara yang dilarang syara. ${ }^{4}$

Pendapat para ulama' di atas dapat dikelompokkan pada dua golongan, yang pertama melarang penerapan fiqh yang tujuannya untuk mengambil hukum yang mudah/ringan, yaitu pendapat Imam al-Ramli> Imam al-Ghazał $\gg$ Imam al-Subki Wahbah Zuhayli. Sedangakn golongan kedua memperbolehkan penerapan fiqh yang tujuannya untuk mengambil hukum yang mudah/ringan yaitu pendapat Imam al-Qarał>mayoritas shałipah dan al-Kamaßibnu al-Humam, 'Izzuddin bin Abd Salam, dan Ibnu Nujaym.

\footnotetext{
${ }^{37}$ Ibid, 175.

38 Ibid, 175.

39 Ibid, 175.

${ }^{40}$ Ibid, 177.

${ }^{41}$ Ibid, 177.

${ }^{42}$ Ibid, 178.

${ }^{43}$ Ibid, 178.
}

62 Moh. Dliya’ul Chaq - Penerapan Figh di Tengah Perbedaan Marbab 
Jika dilihat dari sisi kebutuhan efektifitas hukum serta fungsi hukum sebagai kontrol sosial, maka penerapan fiqh yang lebih tepat adalah fiqh sesuai dengan kondisi masyarakat dan lingkungannya. Sehingga tidak memberatkan masyarakat secara umum dan tidak menimbulkan dampak sentimen antar golongan. Hal ini sesuai dengan asas penerapan hukum Islam berupa penciptaan keringanan (takbfif kemudahan (taysis dan penolakan bahaya serta kerusakan yang kesemuanya berorientasi pada maqa shari dan maslahbd. ${ }^{44}$

Selanjutnya, ketika penerapan hukum di tengah perbedaan Mazhab, sering kali dihadapkan dengan adanya startifikasi qoul ulama'. Ada istilah pendapat yang shahih, ashoh, mu'tamad, lemah dan lain sebagainya. Sebenarnya hal ini merupakan keniscayaan dari adanya justifikasi dalam kajian perbandingan Mazhab yang ada. Bahkan startifikasi pendapat ulama' tersebut malah marak terjadi ada dalam satu Mazhab.

Kondisi yang demikian ini mungkin kurang tepat dan terkesan adanya pembunuhan karakter ulama'. Ketika ada penilaian minus terhadap ulama' tertentu atau pendapatnya yang kemudian diamini oleh generasi setelahnya, maka dalam fakta sejarahnya, pendapat ulama' tersebut kemudian sulit untuk masuk dalam kajian-kajian setelahnya walaupun produk pemikirannya bagus dan benar. Jika pun terpaksa, pendapat ulama yang demikian dapat masuk kajian namun hanya sebatas pelengkap. Tradisi yang fatal.

Dalam kaidah fiqh sendiri, sebuah hasil ijtihad tidak dapat dirusak dengan ijtihad yang lain. Kaidah ini menunjukkan kesetaraan hasil ijtihad atau pendapat ulama'. Fiqh sama sekali tidak mengakui adanya stratifikasi pendapat ulama'. Bahkan ma iyah dengan tegas dan bijak menyatakan, lemahnya pendapat ulama' bukanlah dilihat dari segi istinbatya, melainkan lebih karena pendapat tersebut tidak dikenal luas sebagaimana pendapat yang masyhur. ${ }^{45}$

Ma iyyah melanjutkan bahwa bolehnya penggunaan pendapat ulama' yang pada saat itu belum masyhur dengan ketentuan: (1) meyakini pendapat tersebut ditetapkan oleh ulama', (2) para pelaku hukum memang orang yang terbiasa dan cocok menggunakan pendapat tersebut, (3) dasar pertimbangannya adalah maslhhat dan ada sebab yang mendorong untuk menggunakan pendapat tersebut, (4) mengetahui

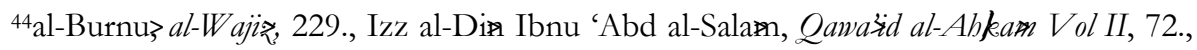
Al-Shatoiral-Muwawrafaqa®l ol II, 4.

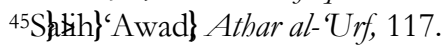


kondisi tempat seperti 'urf dan kebiasaan, dan (5) mengetahui kondisi masa atau waktu. ${ }^{46}$

\section{Simpulan}

Nalar fiqh yang tersusun dari hasil komunkasi antara teks wahyu, nalar mujtahid (aspek teoritis) dan kondisi lingkungan (aspek praktis) meniscayakan adanya perbedaan pendapat (ikhtila $\ngtr$ di dalamnya. Jadi, faktor penyebab fiqh selalu ikhtila $\$$ adalah aspek teoritis dan aspek praktis yang ada dalam fiqh itu sendiri. Hal ini sejatinya membuktikan bahwa fiqh memang ilmiah dan akan selalu dinamis sepanjang masa.

Di samping penyusunannya yang selalu menarik perhatian, penerapan fiqh juga benar-benar membutuhkan perhatian ahli hukum Islam. Di tengah ragam figh hasil ijtihad (ikhtila $\$$ Mazhab), tidak semuanya dapat menjawab kebutuhan masyarakat. Hanya fiqh yang sesuai dengan kondisi lingkungan dan masyarakat yang dapat menjadi hukum yang hidup dan efektif di masyarakat sehingga tidak memberatkan masyarakat secara umum dan tidak menimbulkan dampak sentimen antar golongan. Hal ini sesuai dengan asas penerapan hukum Islam berupa penciptaan keringanan (takhfi $\ngtr$, kemudahan (taysi $\ngtr$ dan penolakan bahaya serta kerusakan yang kesemuanya secara nyata dan jelas berorientasi pada maqa shari dan maslah drt

Dasar pemikiran ini memiliki implikasi logis atas keberlakuan kearifan lokal dan meminimalisir sikap fanatisme Mą̧hab tertentu serta menghilangkan tradisi debat kusir yang berujung pada justifikasi pendapat salah, batal dan lemah. Mengingat semua pendapat fiqh adalah hasil penalaran mujtahid yang disandarkan pada teks wahyu sehingga hasil ijtihad tersebut pasti bersifat asumtif (złnni> yang masih dimungkinkan mengandung kebenaran.

${ }^{46} \mathrm{Ibid}, 117$. 


\section{DAFTAR PUSTAKA}

Abbas, Hasjim. Metodologi Penelitian Hukum Islam. Jombang: PPS UNDAR, 2010.

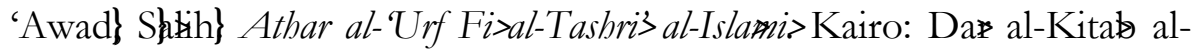
Jaßii'i, t.t.

Azizy, A. Qadri. Ekleksitisme Hukum Nasional: Kompetisi antara Hukum Islam dan Hukum Umum. Jogjakarta: Gama Media, 2002.

Azizy, A. Qadri. Reformasi Bermadæhab. Bandung: Mizan, 2006.

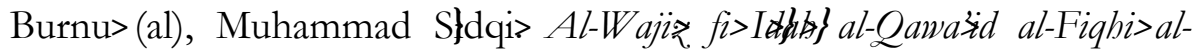
Kulliyah. Riyad:\}Maktabat al-Tawbah, tt.

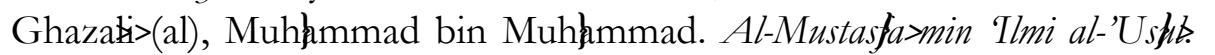
Damaskus: Ar-Risałh, 2010.

Haroen, Nasrun. Ushul Figh I. Jakarta: Logos Publishing House, 1996.

Mahfudz, A. Sahal. "Menggagas Fiqh sosial yang berbasis pada kearifan Lokal", Makalah Kuliah Umum Studium General Kulliyyatusy Syari'ah IKAHA Tebuireng Jombang 8 September 2007 di Tambakberas Jombang (Jombang: 2007)

Mahraban, Muhammad. al-Ijtiha $\$$ wa al-Taqli Bayna al-Afratura al-Tafritet Beirut: Daßal-Kutub al-Ilmiyah, 1971.

Mudzhar, Atho. Membaca Gelombang Ijtihad, Antara Tradisi dan Liberalisasi. Yogyakarta: Titian Ilahi Press, 1998.

Na'im (al), Abdullah Ahmed. Dekontruksi Syariah, terj: Ahmad Suaedy dan Amiruddin ar-Rany. Jogjakarta: LKiS, 2011.

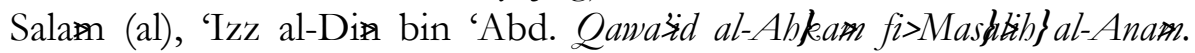
Beirut: Daßal-Kutub al-'Ilmiyyah, t.th.

Shałiłal), Muhammad bin Idris. Al-Um. Beirut: Daæal-Ma'rifah, 1993.

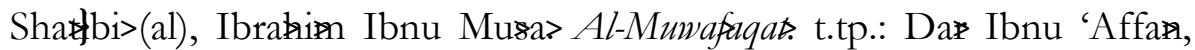
1997.

Umar, Nasaruddin. Argumen Kesetaraan Jender Perspektif Al-Qur'an. Jakarta: Dian Rakyat, 2010.

Wahid, Abdurrahman. "Menjadikan Hukum Islam Sebagai Penunjang Pembangunan", dalam Hukum Islam di Indonesia Pemikiran dan Praktek, ed. Tjun Surjaman, et al. Bandung: Rosda Karya, 1991.

Zahro, Ahmad. "Desakralisasi Kitab Fiqh Sebagai Upaya Reformasi Pemahaman Hukum Islam", Menara Tebuireng, Vol. 2, No. 1, September, 2005.

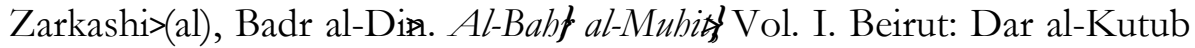
al-Ilmiyyah, 2000. 


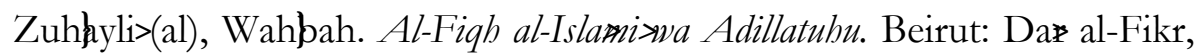
2000. 